\title{
Analysis of the expression and regulation of the gerB spore germination operon of Bacillus subtilis 168
}

\author{
Bernard M. Corfe, ${ }^{1}$ Anne Moir, ${ }^{1}$ David Popham ${ }^{2}$ and Peter Setlow ${ }^{2}$ \\ Author for correspondence: Anne Moir. Tel: +44742 824418. Fax: +44742 728697. e-mail: \\ a.moir@uk.ac.sheffield
}

\begin{abstract}
1 Krebs Institute, Department of Molecular Biology and Biotechnology, University of Sheffield, Western Bank, Sheffield S10 2TN, UK

2 Department of Biochemistry, University of Connecticut Health Center, Farmington, CT 06032, USA
\end{abstract}

\begin{abstract}
The gerB spore germination operon of Bacillus subtilis 168 is a homologue of the gerA spore germination operon. The expression and regulation of the gerB operon has been examined using a lacz transcriptional fusion and the transcriptional start defined. The gerB operon is expressed during sporulation under the control of RNA polymerase containing the forespore-specific sigma factor, $\sigma^{\sigma}$. This is a further homology to the gerA operon, which is similarly regulated. It is predicted from the localization of expression and the encoded primary sequences that the GerB proteins are located at the inner spore membrane.
\end{abstract}

Keywords: Bacillus subtilis, sporulation, germination, gerB expression and regulation, sigma factor

\section{INTRODUCTION}

The production of endospores by Bacillus subtilis is achieved by expression of many sporulation-specific genes in a strict temporal and spatial order. A regulatory cascade operates whereby genes involved in successive stages in the developmental process are regulated by a series of RNA polymerase sigma factors with promoter specificity for those genes. This, and additional levels of control, were reviewed recently by Errington (1993). The sigma factor $\sigma^{\mathrm{G}}$ regulates a number of genes that are expressed solely in the forespore compartment of the sporangium after engulfment by the mother cell. These genes include spoIIIG $(\operatorname{sig} G)$, the structural gene for $\sigma^{\mathrm{G}}$, the ssp genes, encoding small acid-soluble proteins which stabilize spore core macromolecules, and $g p r$, encoding the protease which degrades them during germination (Moir, 1992). Several spore germination genes, i.e. the ger $A$ operon and ger $D$, have been shown to be expressed in the forespore compartment of the sporangium, and are exclusively regulated by $\sigma^{\mathrm{G}}$ (Feavers et al., 1990; Kemp et al., 1991). The ger $A$ operon is concerned with alanine-triggered spore germination and may encode an alanine receptor; the ger $D$ gene is involved in both the known germination pathways, but its function is unknown. We recently reported the nucleotide sequence of the ger $B$ operon of $B$. subtilis and showed that it was a homologue of the ger $A$

Abbreviations: $\mathrm{GDH}$, glucose dehydrogenase; $\mathrm{MU}$, methylumbelliferone; MUG, methylumbelliferyl $\beta$-D-galactoside. operon in terms of both polypeptides encoded and gene organization, despite the two operons being associated with different spore germination pathways (Corfe $e t$ al., 1994). The gerB operon has a potential $\sigma^{\mathrm{G}}$-binding site upstream of the first ORF (Corfe et al., 1994; FajardoCavazos et al., 1991), which may suggest a further degree of homology between the two operons. All three polypeptides encoded by ger $B$ are predicted to be membranelinked to some extent, so the location of ger $B$ expression in spores may indicate whether the proteins are likely to be associated with the inner or outer spore membrane, assuming that they would become associated with the membrane surrounding the compartment in which they are expressed.

\section{METHODS}

Bacterial strains and media. All strains used are listed in Table 1. B. subtilis strains were grown and stored on nutrient agar (Oxoid). Plasmids were constructed in, and prepared from, Escherichia coli strain DH5 $\alpha$. Transformation of B. subtilis was by the method of Anagnostopoulos \& Spizizen (1961) and of E. coli by the method of Mandel \& Higa (1970). Synchronous sporulation experiments were done as described by Sterlini \& Mandelstam (1969) and IPTG-induction of Pspac was as described by Sun et al. (1989).

Plasmid construction. Plasmid pAZ106-gerB was made by cloning the $1.5 \mathrm{~kb}$ HindIII fragment internal to the gerB operon (Corfe, 1992) into the HindIII site upstream of the promoterless lac $Z$ gene of $\mathrm{pAZ106}$ in the correct orientation to give a transcriptional fusion to lac $Z$ (Corfe, 1992). 
Table 1. Bacterial strains and plasmids used in this study

\begin{tabular}{|c|c|c|}
\hline $\begin{array}{l}\text { Strain or } \\
\text { plasmid }\end{array}$ & Relevant genotype or phenotype* & $\begin{array}{l}\text { Source or } \\
\text { reference }\end{array}$ \\
\hline \multicolumn{3}{|c|}{ Bacillus subtilis } \\
\hline PS832 & Prototroph & Laboratory stock \\
\hline SG64 & lac $A 1$ lac $\mathrm{R} 1$ & Errington \& Vogt (1990) \\
\hline BC100 & lac $A 1$ lacR1 gerBB::pAZ106 & SG64 × pAZ109-gerB \\
\hline BC101 & lac A1 lacR1 gerBB::pAZ106 Pspac-sigE & $\mathrm{BC} 100 \times \mathrm{pDG} 180$ \\
\hline BC102 & lac $A 1$ lacR1 gerBB::pAZ106 Pspac-sigF & $\mathrm{BC} 100 \times \mathrm{pRS} 11$ \\
\hline $\mathrm{BC} 103$ & lac A1 lacR1 gerBB::pAZ106 Pspac-sigG & $\mathrm{BC} 100 \times \mathrm{pDG} 298$ \\
\hline \multicolumn{3}{|c|}{ Escherichia coli } \\
\hline $\mathrm{DH} 5 \alpha$ & $\begin{array}{l}\text { supE44 } \Delta \text { lac } U 169(\phi 80 \text { lacZ } \Delta M 15) \text { bsa'R17 } \\
\operatorname{rec} A 1 \text { end } A 1 \text { gyr } A 96 \text { thi-1 relA1 }\end{array}$ & Laboratory stock \\
\hline \multicolumn{3}{|l|}{ Plasmids } \\
\hline pAZ106 & MLS $^{R}$ & Zuberi et al. (1990) \\
\hline pAZ106-ger $B$ & $\mathrm{MLS}^{\mathrm{R}} \operatorname{gerB} \mathrm{B}-\operatorname{lac} Z$ & This study \\
\hline pDG180 & $A p^{R} K^{R}{ }^{R}$ Pspac-sigE & Popham \& Stragier (1991) \\
\hline pRS11 & $\mathrm{Ap}^{\mathrm{R}} \mathrm{Km}^{\mathrm{R}}$ Pspac-sigF & Schmidt et al. (1990) \\
\hline pDG298 & $\mathrm{Ap}^{\mathrm{R}} \mathrm{K}^{\mathrm{R}}$ Pspac-sigG & Sun et al. (1989) \\
\hline p5113 & $\mathrm{Ap}^{\mathrm{R}} \mathrm{Cm}^{\mathrm{R}} \operatorname{ger} B A$ & Corfe et al. (1994) \\
\hline
\end{tabular}

${ }^{*} A \mathrm{p}^{\mathrm{R}}$, ampicillin resistance; $\mathrm{Cm}^{\mathrm{R}}$, chloramphenicol resistance; $\mathrm{Km}^{\mathrm{R}}$, kanamycin resistance; $\mathrm{MLS}^{\mathrm{R}}$, macrolide-lincosamide-streptogramin B resistance.

Enzyme assays. $\beta$-Galactosidase and glucose dehydrogenase (GDH) were assayed as described by Kemp et al. (1991). One unit of $\beta$-galactosidase activity was defined as the amount of enzyme which releases 1 pmol methyl umbelliferone (MU) $\min ^{-1}$, after Zuberi et al. (1987).

Isolation and analysis of gerB mRNA. RNA was extracted from B. subtilis 168 at $0,2,4$ and $6 \mathrm{~h}$ after initiation of sporulation in $2 \times$ SG medium (Goldrick \& Setlow, 1983), and the 5' end of the $\operatorname{ger} B$ mRNA was determined by primer extension analysis (Feavers et al., 1990; Mason et al., 1988). The primers used were (1) a synthetic oligonucleotide 3'-GGTC'T'TGTTAAATCTGTGTGAC-5', which is complemetary to residues $21-42$ in the gerB coding sequence (Corfe et al., 1994), or (2) a second synthetic oligonucleotide 3 '-CCCTGTTTTGCTGCTATA-5', which is complementary to residues $54-72$ in the ger $B A$ coding sequence (Corfe et al., 1994). The synthetic oligonucleotides were labelled with polynucleotide kinase and $\left[\gamma_{-}^{32} \mathrm{P}\right]$ ATP. Samples of primer extended with reverse transcriptase in the presence of RNA (40 $\mu \mathrm{g})$ from sporulating cells were run on $6 \%$ $(\mathrm{w} / \mathrm{v}$ ) polyacrylamide/8 $\mathrm{M}$ urea sequencing gels alongside the four lanes of DNA sequence determinations by the chain termination method, which was carried out using these same primers with plasmid p5113 (Corfe et al., 1994).

\section{RESULTS AND DISCUSSION}

\section{Time of expression of gerB during sporulation}

Synchronous sporulation of strain BC100 (see Table 1) was induced by the resuspension method (Sterlini \& Mandelstam, 1969) and the results are shown in Fig. 1. The time of induction of $\operatorname{ger} B$, as indicated by $\beta$ galactosidase activity from the ger $B-$ lac $Z$ transcriptional fusion, was between 2.5 and $3 \mathrm{~h}$ after resuspension $\left(\mathrm{T}_{2 \cdot 5}-\mathrm{T}_{3}\right)$. The measured activity reached a peak at $\mathrm{T}_{4}$ and subsided thereafter, probably due to the progressive increase in resistance of the forespore to the lysozymedependent extraction procedure used. The samples were

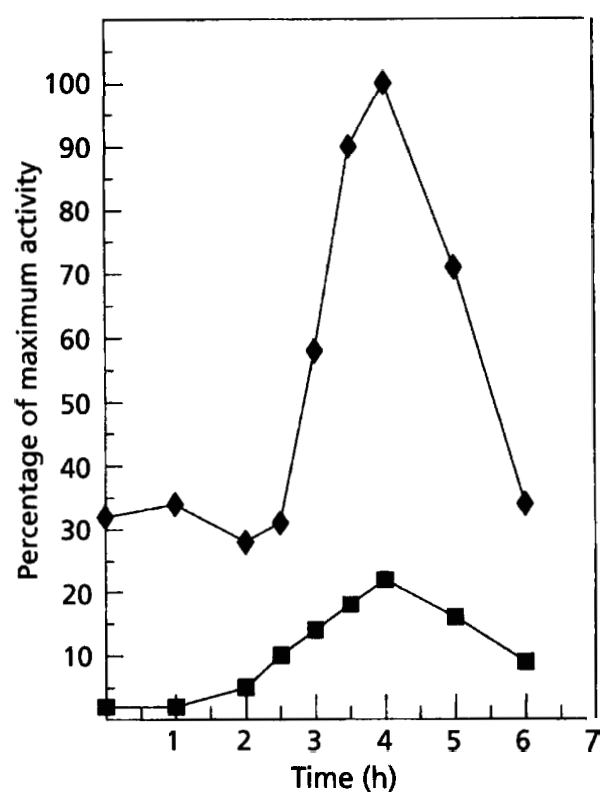

Fig. 1. Time of induction of gerB-lacZ expression during sporulation. $\beta$-Galactosidase levels were measured following induction of synchronous sporulation in strains BC100 $(\diamond)$ and SG64 ( $\boldsymbol{C})$. Enzyme units were calculated per $\mathrm{ml}$ of culture and expressed as a percentage of the maximum value obtained with strain BC100 [2 pmol MUG hydrolysed $\min ^{-1}$ ( $\mathrm{ml}$ culture) $)^{-1}$ ]. Results are the means of ten experiments. 


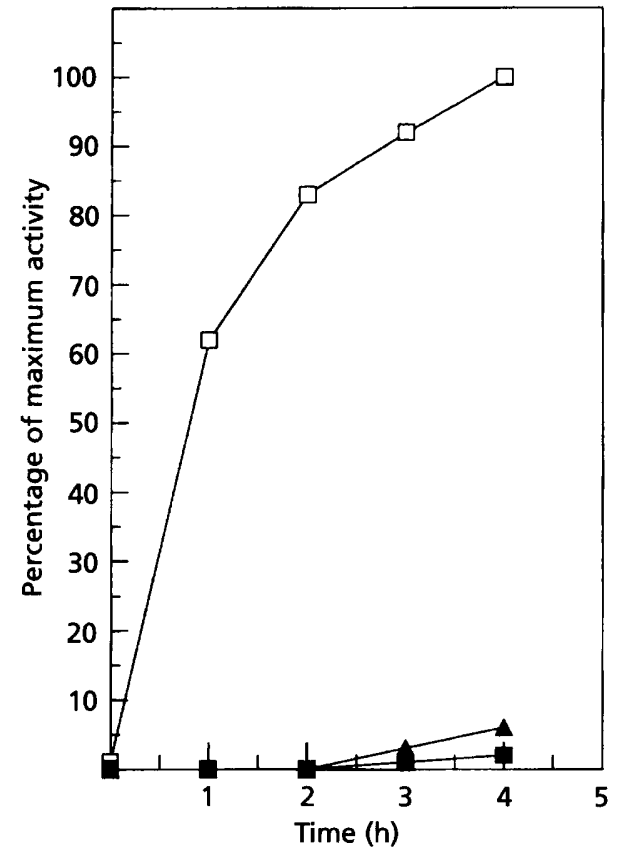

Fig. 2. Induction of gerB-lacZ expression in Pspac-sig genetic backgrounds. $\beta$-Galactosidase was measured at intervals after induction of various sporulation-specific sigma factors in strains BC103 ( $\square$, Pspac-sigG), BC101 ( $\square$, Pspac-sigE), BC102 (A, Pspac-sigf). The data are expressed as a percentage of the maximum activity normalized for the $O_{600}$ of the culture, observed in strain BC103 $\left(950 \mathrm{pmol} \mathrm{min}^{-1}\right.$ per $\mathrm{ml}$ culture of $\left.O D_{600} 1.0\right)$. Data are the means of three independent experiments. Cultures were grown in L-broth containing $5 \mu \mathrm{g}$ kanamycin $\mathrm{ml}^{-1}$ and were induced by the addition of IPTG to a final concentration of $1 \mathrm{mM}$.

also assayed for GDH activity (data not shown), which showed the same kinetics of induction as $\operatorname{ger} B-\operatorname{lac} Z$, and peaked at the same time. Direct comparison of the level of expression observed with that of ger $A-l a c Z$ fusions is not strictly possible as the two fusions were in different genetic backgrounds, but we estimate that the level of ger $B$ expression is about one-fifteenth that of $\operatorname{ger} A$. The mean maximum level of $\beta$-galactosidase activity [ 2 pmol methylumbelliferyl $\beta$-D-galactoside (MUG) hydrolysed $\min ^{-1} \mathrm{ml}^{-1}$ ] was extremely low, but was consistently above the level of the control strain, SG64, lacking the fusion. This control strain of $B$. subtilis has a very low level of endogenous $\beta$-galactosidase activity and is generally considered as having a $\mathrm{Lac}^{-}$phenotype. Nevertheless, the background in the $\mathrm{Lac}^{-}$strain becomes significant at the very low levels of lac $Z$ expression observed in these experiments - presumably the lac $A 1$ allele is slightly leaky. The data presented in Fig. 1 are the mean of ten experiments; although differences in the absolute level of $\beta$-galactosidase of up to twofold were obtained in different sporulation experiments, the profile of time of expression was similar in each case. GDH is regulated by $\sigma^{\mathrm{G}}$, and the time of induction of both gerB and gdh correspond well with the published data for genes regulated by $\sigma^{G}$ (Setlow, 1989).

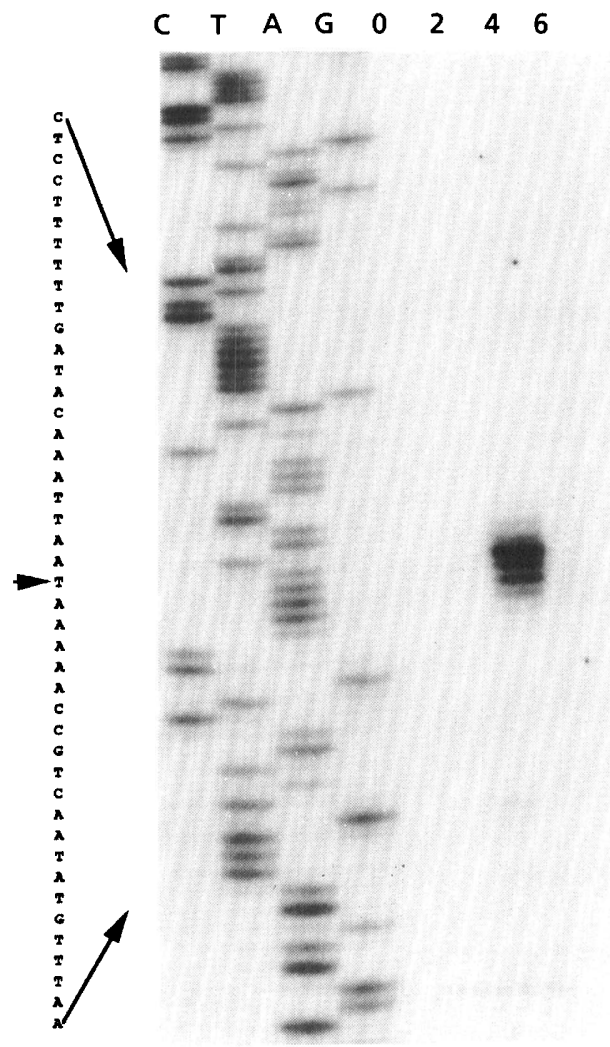

Fig. 3. Primer extension analysis of the $5^{\prime}$ end of ger $B$ mRNA in vivo. RNA was isolated and purified from cells of strain PS832 at $0,2,4$ and $6 \mathrm{~h}$ of sporulation as described in Methods. Samples of these RNAs were hybridized with end-labelled oligonucleotide- 1 and extended with reverse transcriptase. A sample of the same oligonucleotide was also used to prime DNA synthesis with the appropriate dideoxynucleotides on plasmid p5113. Samples were resolved by electrophoresis as described in Methods, and labelled DNA located by autoradiography. The lanes are: $C, T, A$ and $G, D N A$ synthesis reactions with ddGTP, ddATP, ddTTP and ddCTP, respectively; 0 , 2,4 and 6, extended primer with RNA isolated from sporulating cells after $0,2,4$ or $6 \mathrm{~h}$ of sporulation, respectively. The sequence on the left shows the ger $B$ sequence in the region of the extended primer (Corfe et al., 1994). The arrow at the T residue denotes the 5 '-end of gerB mRNA.

Spores of the gerB-lac $Z$ fusion strain were shown to possess $\beta$-galactosidase activity, indicating that the activity was present in spores after mother-cell lysis (data not shown).

\section{Induction of gerB expression}

In order to ascertain the elements responsible for regulation of a sporulation gene, most workers have introduced lac $Z$ fusions into a number of different $\mathrm{Spo}^{-}$ genetic backgrounds. Owing to the very low level of expression of ger $B$ this was not considered feasible. Instead plasmids carrying different inducible sigma factor (sig) genes were introduced into $\mathrm{BC} 100$ (see Table 1). It should be noted that, whilst the Pspac-sigG and -sigE plasmids were autonomously replicating in $B$. subtilis, the Pspac-sigF was integrated into the chromosome. In order 


$\begin{array}{llll}-35 & & -10 & \\ \text { TGAATA } & 17-18 \mathrm{nt} & \text { CATACTA } & \sigma^{\mathrm{G}} \text { consensus } \\ \text { CGATAA } & 18 \mathrm{nt} & \text { GATACAA } & \text { gerB } \\ \text { AGTATA } & 17 \mathrm{nt} & \text { AAAGATA } & \text { gerA }\end{array}$

Fig. 4. Comparison of the $\sigma^{G}$-consensus promoter sequence with the ger $B$ and gerA promoter sequences. The consensus $\sigma^{G}$ promoter sequence in the -10 and -35 regions is from Nicholson et al. (1989) and Sun et al. (1991); the gerB sequence is from Corfe et al. (1994) as determined in Fig. 3 ; the gerA sequence from Feavers et al. (1990). Bold face bases are conserved in $>80 \%$ of all $B$. subtilis promoters transcribed by $\mathrm{E} \sigma^{\mathrm{G}}$. Underlined bases in the ger $B$ promoter which differ from the consensus sequence are found at this position in at least one other $B$. subtilis $\sigma^{G}$-dependent promoter.

to establish in which background the gerB-lac $Z$ fusion would be switched on, the sigma factors were induced in vegetative cultures. The results are shown in Fig. 2. The ger $B$-lac $Z$ fusion is expressed after induction of sig $G$ in vegetative cells, but shows virtually no activity after induction of $s i g E$ or $s i g F$. These results were obtained in three independent experiments. GDH activity was also measured after induction of $\operatorname{sig} G$, and showed a similar profile to ger $B$-directed $\beta$-galactosidase activity (data not shown). It might be expected that a $\sigma^{G}$-dependent promoter, such as gerB, would also show some delayed induction following the expression of $\operatorname{sig} F$, as that would lead to $\sigma^{\mathrm{F}}$-dependent expression of $\operatorname{sig} G$ (Partridge et al., 1991). There is a slight suggestion of some eventual expression of gerB-lacZ after the induction of Pspac-sigF. The very low level observed in this case may be a result of the lower gene dosage of $s i g F$ and the observed weakness of the gerB promoter.

\section{Analysis of gerB mRNA}

Further evidence pertinent to the timing of gerB expression and the promoter sequences involved was obtained by primer extension analysis using RNA obtained from cells $0,2,4$ and $6 \mathrm{~h}$ into sporulation (Fig. 3). This analysis indicated that significant levels of $\operatorname{ger} B$ mRNA were only present at the fourth hour of sporulation. While a number of closely spaced extension products were obtained from $\operatorname{ger} B \mathrm{mRNA}$ at $\mathrm{T}_{4}$, taking the darkest band as the major start point localized the transcription to a $T$ residue $36 \mathrm{nt}$ upstream of the initiating ATG codon (Fig. 3). This same transcription start point was found when the second oligonucleotide was used for primer extension analysis (data not shown). Comparison of sequences upstream of the ger $B$ transcription start point with the consensus for $\sigma^{\mathrm{G}}$-dependent genes (Fig. 4) shows that $\operatorname{ger} B$ exhibits $3 / 6$ matches in the -35 region, and $5 / 7$ matches in the -10 region. In addition, at several of the positions where the ger $B$ sequence differs from the $\sigma^{G}$ consensus sequence, the residues found in ger $B$ are present in at least one other $\sigma^{G}$-dependent promoter (Fig. 4, underlined residues). While the good match between the $\sigma^{\mathrm{G}}$-consensus and ger $B$ promoter sequences is consistent with gerB being a $\sigma^{G}$-dependent gene, there are four very highly conserved positions in the $\sigma^{\mathrm{G}}$-consensus at which ger $B$ differs - two in the -35 region and two in the -10 region. Although the differences between the ger $B$ sequence and the $\sigma^{\mathrm{G}}$-consensus in the -35 region have been shown to have only a small effect on $\sigma^{\mathrm{G}}$-dependent promoter expression, the differences in the -10 region may reduce transcription significantly (Fajardo-Cavazos $e t$ al., 1991). These latter changes may be the reason for the relatively weak transcription of gerB during sporulation. We also note that there are apparently much better matches to the $\sigma^{\mathrm{G}}-10$ and -35 promoter consensus sequences located 4 and $5 \mathrm{bp}$, respectively, closer to the ATG initiation codon (Corfe et al., 1994). Why this potential promoter sequence is not used is unclear.

We conclude that $\operatorname{ger} B$ is transcribed by $\mathrm{E} \sigma^{\mathrm{G}}$ exclusively during sporulation, similarly to the ger $A$ spore germination operon. There was an apparent background level of gerB expression in BC100 during vegetative growth and early sporulation in the synchronous sporulation experiment (see Fig. 1). This residual level is close to the limits of detection and may be explained by some asynchrony of the sporulating cultures, both within and between experiments. The conclusions about the time of expression are reinforced by data which showed that the only significant expression came from induction of sigG, and from the primer extension analysis, which showed that the gerB transcript was only found in late sporulation and not in vegetative or early sporulation cultures.

Both the ger $A$ and $\operatorname{ger} B$ operons encode three proteins which are membrane-associated to some extent, and pairs of which have very similar hydropathy profiles (Feavers $e t$ al., 1985; Zuberi et al., 1987; Corfe et al., 1994). It seems likely that, if the GerB proteins are expressed in the forespore and are membrane-associated, then the membrane in which they are located is the inner forespore membrane, which may be the only intact membrane in spores. This model has already been proposed for the GerA proteins (Feavers $e t$ al., 1990) and is in accord with models that suggest that the initial events of spore germination occur at the inner membrane (Keynan, 1978).

\section{ACKNOWLEDGEMENTS}

We would like to thank Dr E. H. Kemp for assistance with the enzyme assays, and Dr P. Stragier and Professor R. Losick for the gifts of the Pspac-sig plasmids. This work was supported by SERC research grant GR/H09164, and a grant from the National Institutes of Health, GM19698.

\section{REFERENCES}

Anagnostopoulos, C. \& Spizizen, J. (1961). Requirements for transformation in Bacillus subtilis. J Bacteriol 81, 741-746.

Corfe, B. M. (1992). A molecular genetical analysis of the gerB spore germination gene of Bacillus subtilis $168 . \mathrm{PhD}$ thesis, University of Birmingham, UK.

Corfe, B. M., Sammons, R. L., Smith, D. A. \& Mauël, C. (1994). The gerB region of the Bacillus subtilis 168 chromosome encodes a homologue of the ger $A$ spore germination operon. Microbiology 140, 471-478. 
Errington, J. (1993). Bacillus subtilis sporulation: regulation of gene expression and control of morphogenesis. Microbiol Rev 57, 1-33.

Errington, J. \& Vogt, C. H. (1990). Isolation and characterization of mutations in the gene encoding an endogenous Bacillus subtilis $\beta$-galactosidase and its regulator. J Bacteriol 172, 488-490.

Fajardo-Cavazos, P., Tovar-Rojo, F. \& Setlow, P. (1991). Effect of promoter mutations and upstream deletions on the expression of genes coding for small, acid-soluble proteins of Bacillus subtilis. $J$ Bacteriol 173, 2011-2016.

Feavers, I. M., Miles, J. S. \& Moir, A. (1985). The nucleotide sequence of a spore germination gene $($ ger $A)$ of Bacillus subtilis 168 . Gene 38, 95-102.

Feavers, I. M., Foulkes, J., Setlow, B., Sun, D., Nicholson, W., Setlow, P. \& Moir, A. (1990). The regulation of transcription of the ger $A$ spore germination operon of Bacillus subtilis. Mol Microbiol 4, 275-282.

Goldrick, S. \& Setlow, P. (1983). Expression of a Bacillus megaterium sporulation-specific gene during sporulation of Bacillus subtilis. $J$ Bacteriol 115, 1459-1462.

Kemp, E. H., Sammons, R. L., Moir, A., Sun, D. \& Setlow, P. (1991). Analysis of transcriptional control of the gerD spore germination gene of Bacillus subtilis 168. J Bacteriol 173, 4646-4652.

Keynan, A. (1978). Spore structure and its relation to resistance, dormancy and germination. In Spores VII, pp. 43-53. Edited by G. Chambliss \& J. C. Vary. Washington, DC: American Society for Microbiology.

Mandel, M. \& Higa, A. (1970). Calcium-dependent bacteriophage DNA infection. J Mol Biol 53, 159-162.

Mason, J. M., Hackett, R. H. \& Setlow, P. (1988). Regulation of expression of genes coding for small, acid-soluble proteins of Bacillus subtilis spores: studies using lac $Z$ gene fusions. $J$ Bacteriol 170, 239-244.

Moir, A. (1992). Compartmentalised gene expression during Bacillus subtilis sporulation. In Prokaryotic Structure and Function: a New Perspective, pp. 275-296. Edited by S. Mohan, C. Dow \& J. A. Cole. Cambridge: Cambridge University Press.
Nicholson, W. L., Sun, D., Setlow, B. \& Setlow, P. (1989). Promoterspecificity of $\sigma^{\mathrm{G}}$-containing RNA polymerase from sporulating cells of Bacillus subtilis: identification of a group of forespore-specific promoters. J Bacteriol 171, 2708-2718.

Partridge, S. R., Foulger, D. \& Errington, J. (1991). The role of $\sigma^{F}$ in prespore-specific transcription in Bacillus subtilis. Mol Microbiol 5, 757-767.

Popham, D. L. \& Stragier, P. (1991). Cloning, characterization, and expression of the spoVB gene of Bacillus subtilis. J Bacteriol 173, 7942-7949.

Schmidt, R., Margolis, P., Duncan, L., Coppolacchia, R., Moran, C. P., Jr. \& Losick, R. (1990). Control of development transcription factor $\sigma^{\mathbf{F}}$ by sporulation regulatory proteins SpoIIAA and SpoIIAB in Bacillus subtilis. Proc Natl Acad Sci US A 87, 9221-9225.

Setlow, P. (1989). Forespore-specific genes of Bacillus subtilis: function and regulation of expression. In Regulation of Prokaryotic Development, pp. 211-221. Edited by I. Smith, R. A. Slepecky \& P. Setlow. Washington, DC: American Society for Microbiology. Sterlini, J. M. \& Mandelstam, J. (1969). Commitment to sporulation in Bacillus subtilis and its relationship to development of actinomycin resistance. Biochem J 113, 29-37.

Sun, D., Stragier, P. \& Setlow, P. (1989). Identification of a new $\sigma$ factor involved in compartmentalized gene expression during sporulation of Bacillus subtilis. Genes \& Dev 3, 141-149.

Sun, D., Fajardo-Cavazos, P., Sussman, M. D., Tovar-Rojo, T., Cabrera-Martinez, R. M. \& Setlow, P. (1991). Effect of chromosome location of Bacillus subtilis forespore genes on the spo gene dependence and transcription by $\mathrm{E} \sigma^{\mathrm{F}}$ : identification of features of good $\mathrm{E} \sigma^{\mathrm{F}}$-dependent promoters. J Bacteriol 171, 7867-7874.

Zuberi, A. R., Moir, A. \& Feavers, I. M. (1987). The nucleotide sequence and gene organization of the ger $A$ spore germination operon of Bacillus subtilis 168. Gene 51, 1870-1876.

Zuberi, A. R., Ying, C., Weinreich, M. R. \& Ordal, G. W. (1990). Transcriptional organisation of a cloned chemotaxis locus of Bacillus subtilis. J Bacteriol 172, 1870-1876.

Received 16 May 1994; revised 11 July 1994; accepted 20 July 1994 